\title{
A One-Piece Ocular Drainage Implant for Glaucoma Surgery: A Preliminary Report
}

\author{
By M. Kivalo, C. Raitta and T. Mononen \\ Department of Anatomy, College of Veterinary Medicine, and Department of Ophthalmology, Helsinki Uni- \\ versity Central Hospital, Helsinki, Finland.
}

\begin{abstract}
Kivalo, M., C. Raitta and T. Mononen: A one-piece ocular drainage implant for glaucoma surgery: A preliminary report. Acta vet. scand. 1992, 33, 317-324. - A one-piece silicone filtration implant for glaucoma surgery was evaluated in 18 normotensive rabbits. During the follow-up period of 60 days the function of the implant and the effect of the implant on intraocular pressure (IOP) and local reaction in operated eyes were examined.

Mean IOP in operated eyes during the whole follow-up period stayed in a level that was statistically significantly $(p<0.001)$ lower than the preoperative starting value. Despite of a slight inflammatory reaction in the immediate postoperative period the implants were well tolerated. No marked foreign body reaction were noted around the implants in histological sections. In 3 eyes the implants had to be removed due to complications caused by surgical technique.
\end{abstract}

fistulating surgery.

\section{Introduction}

Normal intraocular pressure (IOP) is maintained by the balance of aqueous secretion and outflow. Disturbed balance, mostly due to increased outflow resistance, leads to raised IOP which is a risk factor for nerve fibre loss causing progressive optic nerve atrophy and a condition called glaucoma. It is one of the leading causes of blindness in humans and occurs in animals as a result of trauma, uveitis, lens luxation or dysgenesis of the iridocorneal angle.

Uncontrolled glaucoma results in progressive loss of vision and ultimately blindness. The rationale for treatment is to enhance blood perfusion of the optic disc which can be achieved by the reduction of IOP. The most effective means to reduce pressure is fistulating surgery.

The treatment of glaucoma is either medical, surgical or a combination of both. Parasym- phatomimetics improve the outflow of aqueous and $B$-adrenergic antagonists and carbonic anhydrase inhibitors reduce the secretory activity of the ciliary epithelium. The purpose of surgical treatment is to create a new channel for the aqueous humor to leave the eye. Fistulating surgery fails in high risk eyes due to scarformation leading to filtration bleb failure. Among risks for bleb failure is young age of the patient, secondary glaucoma and ocular inflammation. Miller et al. (1989) showed in an animal model that scleral fistulas were blocked by scartissue by the 17 th day after the operation. When conventional filtration operations fail to control IOP, ocular drainage implants offer a new alternative in treatment. At present no commercial implants made specially for domestic animals (dogs and cats) are available. Since implants intented for use in the human eye are not necessarily suitable for use in the ani- 


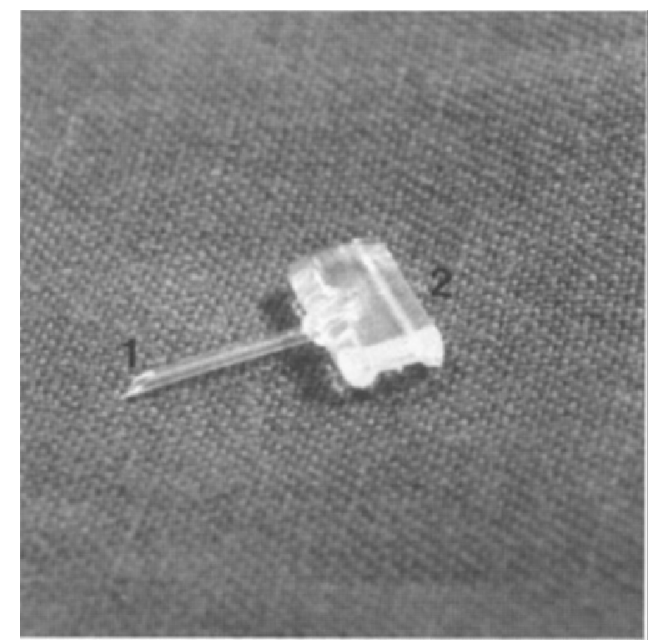

Figure 1. A one-piece filtration implant for glaucoma surgery consists of (1) a silicone tube that is placed into the anterior chamber; (2) a subconjunctivally situated silicone band.

mal eye as such, there is a need for a readily available economical implant in veterinary medicine.

The purpose of this study is to evaluate a low-cost, easy to make silicone implant for veterinary use.

\section{Material and methods}

A $10 \mathrm{~mm}$ long silicone strip, width $5.7 \mathrm{~mm}$, height $1.25 \mathrm{~mm}$, with a U-shaped cross section (Retinal Detachment Band no 20, Storz) was used to construct the implant (Fig.1). A small notch was cut in one side wall and a 10 $\mathrm{mm}$ long medical grade silicone tube with 0.3 $\mathrm{mm}$ inside diameter and $0.64 \mathrm{~mm}$ outside diameter was adhered to the notch with Medical Adhesive Type A (Silastic ${ }^{R}$ ). Both ends of the silicone tube were bevelled to $45^{\circ}$ angle to give maximum opening. The sharp edges at both ends of the silicone strip were rounded off.

Eighteen adult normotensive albino rabbits were used for the experiment. They were divided into 3 groups of 4 and 1 group of 6 animals for the different follow-up periods of 7, 17, 30 and 60 days. A group of 5 rabbits of the same age served as a control for the IOP measurements.

The animals were anesthetized with a combination of xylazin hydrochloride (Rompun ${ }^{\mathrm{R}}$, $20 \mathrm{mg} / \mathrm{ml}) 5 \mathrm{mg} / \mathrm{kg}$ and ketamine hydrochloride $\left(\mathrm{Ketalar}^{\mathrm{R}}, 50 \mathrm{mg} / \mathrm{ml}\right) 15 \mathrm{mg} / \mathrm{kg}$ intramuscularly. The cornea and conjunctiva were topically anesthetized with oxybuprocaine hydrochloride (Obucain ${ }^{\mathrm{R}}, 4 \mathrm{mg} / \mathrm{ml}$ ).

With an operating microscope a fornix based 90 degree incision was made in the dorsal limbus. Conjunctiva and Tenon's capsule were separated from the sclera. The silicone implant was inserted into the thus formed pocket $4 \mathrm{~mm}$ posterior from the limbus with the concave side down and sutured at both ends with one 8-0 silk suture (Virgin Silk ${ }^{\mathrm{R}}$, Ethicon) to the sclera. A $23 \mathrm{G}$ sterile needle was used to penetrate the cornea into the anterior chamber at the limbus. The silicone tube was cut to a length to reach the pupil and inserted into the anterior chamber through the paracentesis tract. Contact with the anterior surface of the iris and corneal endothelium was avoided. Conjunctiva was tightened over the implant and sutured with continuous 8-0 silk suture (Virgin Silk ${ }^{\mathrm{R}}$, Ethicon) at the limbus. $0.4 \mathrm{mg}$ dexamethasone phosphate (Fortecortin ${ }^{\mathrm{R}}, 4 \mathrm{mg} / \mathrm{ml}$ ) was injected into the ventral subconjunctival tissues.

All animals received as a systemic antibiotic trimetoprim $2.5 \mathrm{mg} / \mathrm{kg}$ and sulphadoxine 12.5 $\mathrm{mg} / \mathrm{kg}$ (Borgal ${ }^{\mathrm{R}}$ vet) subcutaneously for 4 days. Locally chloramphenicol eye ointment (Oculo-Klorita ${ }^{\mathrm{R}}, 10 \mathrm{mg} / \mathrm{ml}$ ) and atropin (Of$\tan$ Atropin $^{\mathrm{R}}, 1 \%$ ) were applied twice a day for four days.

Measurement of the IOP with a hand-held applanation tonometer $\left(\right.$ Tonopen $^{\mathrm{R}}$ ) and bio- 


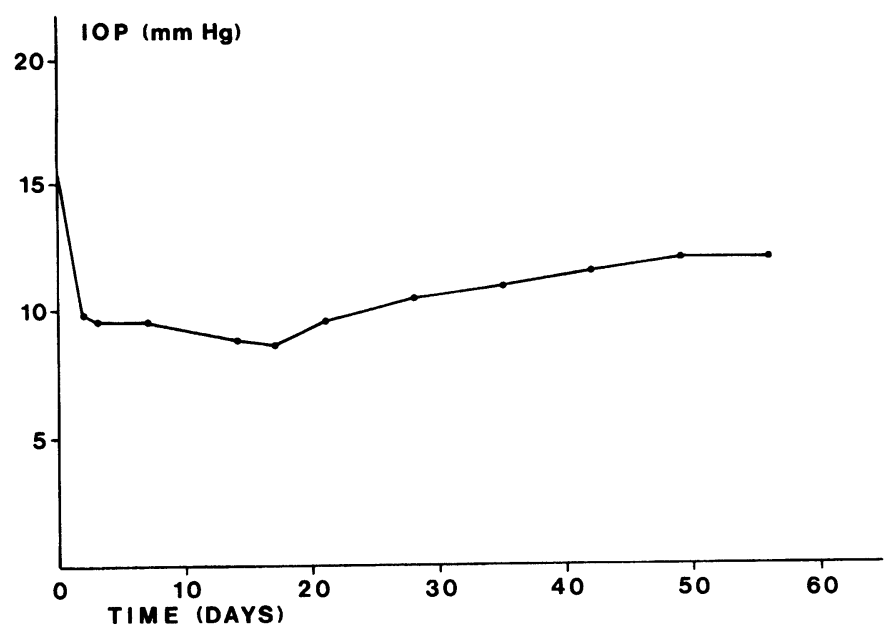

Figure 2. Postoperative intraocular pressure (IOP) during the follow-up period presented as a moving average of 3 consecutive measurements.

microscopical examination were performed daily for the first 3 postoperative days and then once a week for the rest of the followup period.

The follow-up period for each group of animals were 7, 17, 30 and 60 days, after which the animals were euthanized. The eyes were enucleated and immediately fixed in $10 \%$ neutral phosphate buffered formaldehyde. For histological examination the eyes were embedded in paraffin and cut with a microtome to $4 \mu \mathrm{m}$ thick sections and stained with hematoxylin-eosine.

Paired T-test was used for statistical analysis of the material.

\section{Results}

Local edema and hyperemia of the conjunctiva was noted at the site of surgery during the first week after the operation.

On the first post-operative day fibrin accumulations were seen in the anterior chamber. They were mostly found around the silicone tube and between the tube and iris. Most of the fibrin disappeared from the anterior chamber between the third and seventh postoperative days, the remaining fibrin beeing adhered to the outer surface of the tube.

The effect of the operation to the IOP during the follow-up period is seen in Fig.2. The post-operative pressure maintained an even level during the first 4 weeks after the operation before showing a tendency to increase. During the follow-up period the mean IOP stayed lower than the pre-operative starting value. No changes in the IOP were noted in the control group.

No great changes in anterior chamber depths were seen during the follow-up period. After the operation the anterior chambers were shallow for 1 to 3 days. At the inspection after day 7 no shallow anterior chambers were noted.

On 3 occasions the implants eroded through the conjunctiva and had to be removed. These happened on day 7,14 and 21 .

Signs of iritis (miosis, congestion of the iris, fibrin in the anterior chamber) were seen in 1 


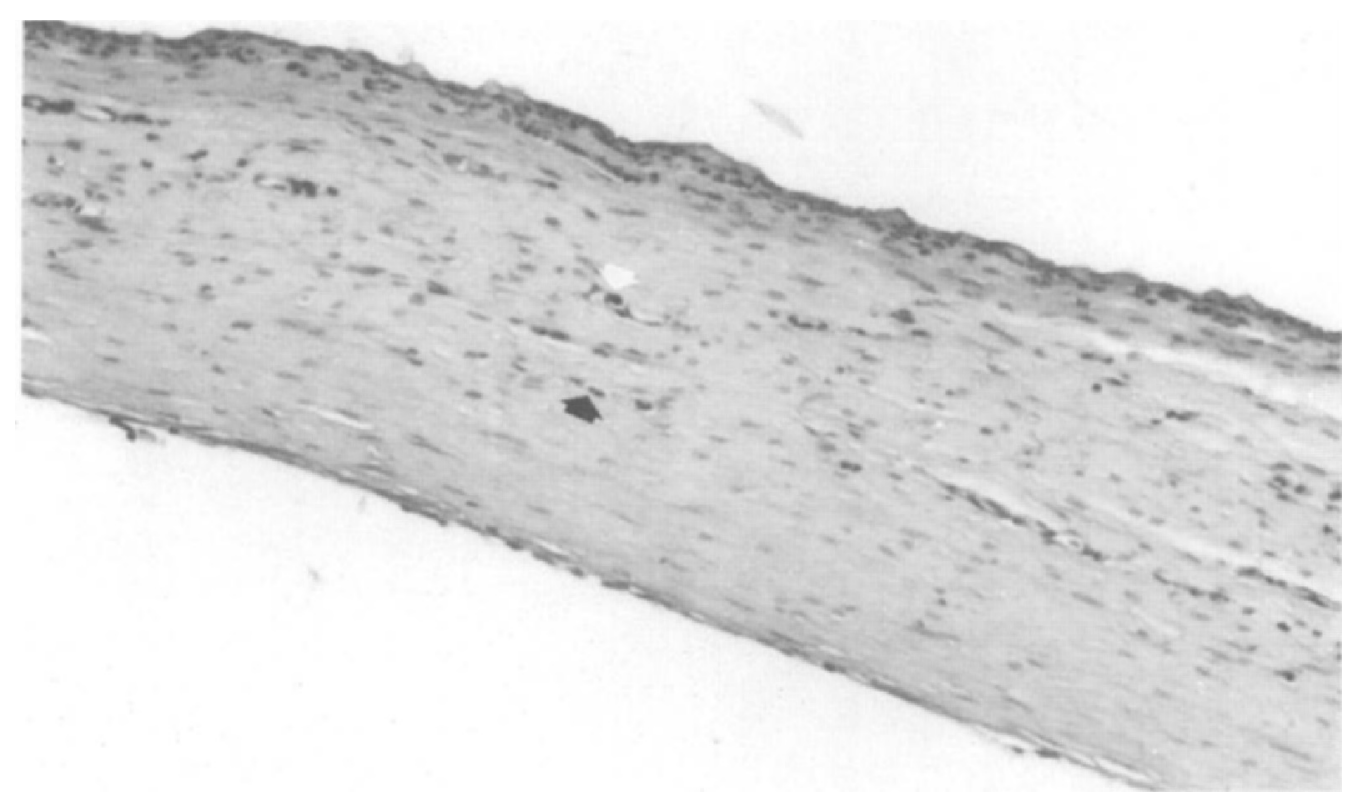

Figure 3. A section of the filtration bleb wall above the silicone implant 60 days after the operation showing a layer of connective tissue with well organized collagen bundles, mononuclear cells (white arrow) and occasional polymorphonuclear leucocytes (black arrow) $(\times 450)$.

eye at the 3rd post-operative day and it was treated with local dexamethasone eye ointment (Oftan-Dexa-Chlora ${ }^{\mathrm{R}}$ ).

\section{Histology}

All implants were removed from the enucleated eyes after fixation. None of the implants were adhered to the surrounding tissues.

At day 7 the implants were surrounded by a thin layer of loose connective tissue with irregularly arranged bundles of collagen. A moderate amount of mononuclear and polymorphonuclear leucocytes were lining the site of the implant, most of the cells beeing at the vicinity of the limbal incision. In 1 animal a local area of necrotic material containing autolytic cells was found under the implant. This was probably due to hemorrhage during surgery.
The capillaries of the iris were dilated in all eyes, no other histological signs of iritis were noted. In 1 animal the end of the silicone tube was adhered to the anterior side of the iris. In 2 animals eryhtrocytes were found in the filtration angle and in the trabecular meshwork.

At day 17 the thickness of the layer of fibrous tissue around the site of the implant had not increased much but it had become more dense and the collagen bundles were more organized. The number of polymorphonuclear and mononuclear leucocytes had decreased, mononuclear cells beeing the dominating cell type. They were mostly found lining the border of the implant. Capillary proliferation of the iris tissue was seen on the posterior surface of the iris in 1 eye. No changes were noted in the filtration angle or in the trabecular meshwork. 
At day 30 the layer of connective tissue lining the site of the implant was of equal thickness as in the previous samples. The collagen bundles were well organized. The number of polymorphonuclear and mononuclear cells had still decreased, mononuclear cells beeing clearly in the majority and found almost solely lining the border of the implant and fibrous tissue. The persistence of mononuclear cells was propably a result of a mild foreign body reaction towards silicone. No changes were noted in the structures of the anterior chamber.

Samples studied 60 days after the operation resembled very much those of the previous group. The layer of connective tissue was mature with well organized collagen bundless (Fig. 3). Only single mononuclear cells and polymorphonuclear leucocytes were found. In 1 eye there were signs of local adherence between posterior cornea and anterior iris. No similar changes were noted in other sections.

\section{Discussion}

The aqueous humor is formed by both secretion and diffusion by the epithelium of the ciliary processes in the posterior chamber. Most of it flows through the pupil into the anterior chamber and filtrates through the trabecular meshwork of the iridocorneal angle into the intrascleral venous plexus. Small amount is absorbed through the iris root and anterior face of the ciliary muscle. Aqueous humor maintains intraocular pressure, provides nutrition for the cornea and supports the metabolism of the lens. Mean applanation IOP of a normal human population is $16 \pm 2,5 \mathrm{~mm} \mathrm{Hg}$.

Slatter (1990) reports that according to various sources the normal canine IOP measured with Shiøtz indentation tonometry varies between 14-30 mm Hg. Differences in ocular rigidity among individuals, prior medication, patient cooperation and state of the instrument explain the great range. Applanation tonometry is less affected by these and gives more reliable readings.

Variation of $2-3 \mathrm{~mm} \mathrm{Hg}$ in tonometric readings is caused by each heartbeat due to the fluctuation in the intraocular vascular volume. Respiration causes a slower variation.

The maintenance of the intraocular pressure is mainly dependant on 2 factors: The rate of secretion of aqueous and outflow resistance. The normal flowrate of aqueous humor in humans and in canine is about $0.20 \mu \mathrm{l} / \mathrm{min}$ per $\mathrm{mm} \mathrm{Hg}$ of intraocular pressure (Newell \& Ernest 1974, Slatter 1990).

Surgical treatment is indicated when glaucoma control fails despite of maximal tolerated medication or if there is progress in visual field defects and in the degree of optic nerve atrophy. The purpose of the surgical treatment is either to help the drainage of aqueous humor through the defective trabecular meshwork or completely bypass the iridocorneal angle by channeling intraocular fluid through a tube to a reservoir situated in the subconjunctival space.

The latter can be accomplished with different types of drainage implants. These consists usually of a disk made out of polymethylmetacrylate (PMMA) (Molteno et al. 1976) or of a silicone band (Schocket et al. 1982, Joseph et al. 1986) connected to a silicone tube.

Major postoperative problems in drainage implant surgery are: flat anterior chamber and hypotony in the immediate postoperative period, excessive fibrosis around the implant with IOP increase, anterior chamber hemorrhage, synechia formation and cataract.

To overcome the complications caused by postoperative hypotony, the silicone tube of the implant can be provided with a pressure 
sensitive valve (Hitchings et al. 1987, Krupin et al. 1976) or the implant may be inserted using a 2-stage procedure (Molteno et al. 1984, Molteno et al. 1986). This consists of inserting the episcleral plate or band in the first stage and several weeks later opening or inserting the silicone tube into the anterior chamber. In the 2-stage procedure the time interval allows enough fibrotic tissue to encapsulate the episcleral part of the implant increasing resistence in absorption and thus preventing prolonged postoperative hypotony.

Excessive fibrosis around the collective system can however lead to tube obstruction and also diminish the permeability and the surface area of the filtration bleb.

The use of antifibrotic agents (Molteno et al. 1976, Molteno 1983) may partly control excessive scartissue formation.

Most implants used in humans are not suitable for use in animals as such. Their standardized size does not always fit the varying size of the globe of different species or breeds. Their cost is another restricting factor.

The implant made for the present study is composed of readily available low cost materials. In contrast to the Schocket tube and gutter model it can be put together before any surgical procedures to shorten the actual operation time (Schocket et al. 1982).

The construction differs from that of most commercial models in not having a pressure sensitive valve at the proximal end of the silicone tube. This was not considered necessary since post-operative flat anterior chamber is not a frequent complication in animal eyes (Bedford 1989) probably because of species differencies in tissue rigidity and aqueous formation. The presence of the valve also increases the risk of fibrotic material blocking the tube.
If desired, a valve can easily be constructed at the proximal end of the silicone tube by closing the end of the tube with the same silicone adhesive used to fasten the tube to the strip and cutting at the side of the tube a slit to act as a valve. The proper length of the slit can be determined manometricly to give the valve a desired opening pressure, usually between 4 and $20 \mathrm{~mm} \mathrm{Hg}$ (Hitchings et al. 1987, Krupin et al. 1980).

No flat anterior chambers of long duration were encountered in the animals used in this study. The anterior chambers stayed shallow for 1 to 3 days post-operatively. A contributing factor was the use of needle paracentesis to minimize aqueous leakage when introducing the silicone tube into the anterior chamber and the size of the silicone strip.

The effect of the procedure on IOP can be seen in Fig 2. The pressure maintained an even level for the first 4 weeks before it showed an inclining tendency. This was probably caused by decreased absorption of the aqueous humor as a consequence of the thickening of the scartissue around the implant. However, during the lenght of the follow-up period the mean IOP of operated eyes stayed in a level that is statistically significantly lower $(\mathrm{p}<0.001)$ than the pre-operative value. No changes were noted in the IOP in control eyes.

An adequate surface area of the implant is important to provide sufficient absorption of aqueous. Molteno (1981) recommends an implant with surface area of $270 \mathrm{~mm}^{2}$, Hitchings et al. (1987) report that $800 \mathrm{~mm}^{2}$ would be sufficient. Schocket tube and gutter device has a surface area of $900 \mathrm{~mm}^{2}$ (Schocket et al. 1982). The total absorptive surface area around the implant used in this study was about $114 \mathrm{~mm}^{2}$ and can be increased by lenghtening the silicone strip if needed. 
Structure of the bleb wall that surrounds the implant is another factor that controls the absorption of aqueous. Excessive scartissue decreases absorption and prevents the implant from functioning properly. Chemical antifibroblast agents (Pasquale et al. 1992, Wilson et al. 1991) have been used to reduce fibrosis but so far no satisfactory method has been found. Implant erosion through the conjunctiva is a commonly reported complication (Krupin et al. 1983, Hitchings et al. 1987, Sherwood et al. 1987). In this study this happened in 3 eyes and the implants had to be removed (on 7th, 14th and 21st post-operative day). Implant removal caused no complications in the operated eyes. These eyes were excluded from the statistical material.

In 1 eye the cause for erosion was the placement of the implant too close, about $3 \mathrm{~mm}$, to the limbus causing excessive pressure on the limbal sutures at the site of the silicon tube entering the anterior chamber. The other 2 were inadequately sutured to the sclera and moved allowing the edge of the silicone strip to penetrate through the limbal wound. To avoid these complications a limbal rather than fornix based incision might be better by placing less tension on the sutures. The silicone strip should be situated more posteriorly from the limbus (Schocket et al. 1982, Sarkies \& Hitchings 1985) and if it's length is increased the ends must be inserted under the rectus muscles.

In species with greater scleral thickness than in rabbits introducing the silicone tube into the anterior chamber under a scleral flap would reduce the risk of the tube eroding through the conjunctival tissues (Sherwood et al. 1987).

Post-operative fibrin formation can prevent the implant from working properly by blocking the tube that channels the aqueous out of the anterior chamber. Steroids and non ster- oid anti-inflammatory drugs (NSAID) have been used to diminish local inflammatory reaction and reduce fibrin formation.

In the first group of animals the patency of the tubes was tested by injecting fluorescein solution into the anterior chamber before euthanasia and observing it appear in the filtration bleb. In other animals the implants were tested after they were removed from the enucleated eyes and found to be patent.

According to different sources (Schocket et al. 1982, Krupin et al. 1983, Sarkies \& Hitchings 1985, Schocket et al. 1985, Sherwood et al. 1987, Krupin et al. 1988, Fellman \& Lynn 1989) the success rate in glaucoma implant surgery in humans varies between $50 \%$ and $95 \%$. The outcome depends greatly on the type of glaucoma and on the type of the implant used.

For veterinary patients with congenitally narrow iridocorneal angle or when other methods fail to control IOP ocular drainage implants offer an alternative to enucleation.

\section{Acknowledgements}

This work was supported by a grant from The College of Veterinary Medicine and The Finnish Foundation of Veterinary Medicine.

\section{References}

Bedford PGC: A clinical evaluation of a one-piece drainage system in the treatment of canine glaucoma. J. small Anim. Pract. 1989, 30, 68-75.

Fellman RL, Lynn JR: Modern-day ocular drainage implants. Clinical Signs in Ophthalmology 1989, XI, 2-16.

Hitchings RA, Joseph $N H$, Sherwood MB, Lattimer $J$, Miller $M$ : Use of one-piece valved tube and variable surface area explant for glaucoma drainage surgery. Ophthal. 1987, 94, 1079-1083.

Joseph NH, Sherwood MB, Trantas G, Hitchings $R A$, Lattimer $L:$ A one-piece drainage system for glaucoma surgery. Trans. ophthal. Soc. U.K. 1986, 105, 657-664.

Krupin T, Podos SM, Becker B: Valve implants in 
filtering surgery. Amer. J. Ophthal. 1976, 81, 232-235.

Krupin T, Kaufman P, Mandell A, Ritch R, Asseff C, Podos SM, Becker B: Filtering valve implant surgery for eyes with neovascular glaucoma. Amer. J. Ophthal. 1980, 89, 338-343.

Krupin T, Kaufman P, Mandell AI, Terry SA, Ritch $R$, Podos SM, Becker B: Long-term results of valve implants in filtering surgery for eyes with neovascular glaucoma. Amer. J. Ophthal. 1983, 95, 775-782.

Krupin T, Ritch R, Camras CB, Brucker AJ, Muldoon TO, Serle J, Podos SM, Sinclair SH: A long Krupin-Denver valve implant attached to a $180^{\circ}$ scleral explant for glaucoma surgery. Ophthal. 1988, 95, 1174-1180.

Miller MH, Grierson I, Unger WI, Hitchings RA: Wound healing in an animal model of glaucoma fistulizing surgery in the rabbit. Ophthal. Surgery $1989,20,350-357$.

Molteno ACB, Straughan JL, Ancker E: Control of bleb fibrosis after glaucoma surgery by antiinflammatory agents. S. Afr. med. J. 1976, 50, 881-885.

Molteno ACB, Straughan JL, Ancker E: Long tube implants in the management of glaucoma. S. Afr. med. J. 1976, 50, 1062-1066.

Molteno ACB: The optimal design of drainage implants for glaucoma. Trans. Ophthal. Soc. N.Z. 1981, 33, 39-41.

Molteno $A C B$ : The use of draining implants in resistant cases of glaucoma. Late results of 110 operations. Trans. Ophthal. Soc. N.Z. 1983, 35, 94-97.

Molteno ACB, Ancker E, Van Biljon G: Surgical technique for advanced juvenile glaucoma. Arch. Ophthal. 1984, 102, 51-57.

Molteno ACB, Polkinghorne PJ, Bowbyes JA : The vicryl tie technique for inserting a draining implant in the treatment of secondary glaucoma. Aust. N. Z. J. Ophthal. 1986, 14, 343-354.

Newell FW, Ernest TJ: Ophthalmology. Principles and concepts. Third Edition. The C. V. Mosby Company, Saint Louis 1974, 73.

Pasquale LR, Thibault D, Dorman-Pease ME, Quigley $H A$, Jampel $H D$ : Effect of topical mitomycin $\mathrm{c}$ on glaucoma filtration surgery in monkeys. Ophthal. 1992, 99, 14-18.
Sarkies NJC, Hitchings RA: Silicone tube and gutter in advanced glaucoma. Trans. ophthal. Soc. U.K. 1985, 104, 133-136.

Schocket SS, Lakhanpal V, Richards RD: Anterior chamber tube shunt to an encircling band in the treatment of neovascular glaucoma. Ophthal. 1982, 89, 1188-1194.

Schocket SS, Nirankari VS, Lakhanpal V, Richards $R D$, Lerner $B C$ : Anterior chamber tube shunt to an encircling band in the treatment of neovascular glaucoma and other refractory glaucomas. A Long-term Study. Ophthal. 1985, 92, 553-562.

Sherwood MB, Joseph NH, Hitchings RA: Surgery for refractory glaucoma. Results and complications with a modified Schocket technique. Arch. Ophthal. 1987, 105, 562-569.

Slatter D: Fundamentals of veterinary ophthalmology. Second edition. W.B. Saunders Company, Philadelphia 1990, 106.

Slatter D: Fundamentals of veterinary ophthalmology. Second edition. W.B. Saunders Company, Philadelphia 1990, 340.

Wilson RM, Lee DA, Baker RS, Goodwin TL, Wooten $F$ : The effects of topical mitomycin on glaucoma filtration surgery in rabbits. J. Ocul. Pharmacol. 1991, 7, 1-8.

\section{Sammanfattning \\ Ett ögondränerings implant för glaukomkirurgi: En preliminär studie.}

Ett filtrationsimplantat av silikon i ett stycke för glaukomkirurgi evaluerades i 18 kaniner med normalt ögontryck.

Implantatets funktion, inverkan på ögontryck och lokal reaktion $\mathrm{i}$ opererade ögon uppföljdes under 60 dagar.

Medelvärdet av ögontrycket stannade under hela uppföljningstiden på en nivå, som var statistiskt signifikant lägre än det preoperativa värdet. Med undantag av en lindrig lokal reaktion just efter operationen, tolererades implantaten väl. Ingen nämnvärd främmandekropp reaktion förekom i histologiska preparat. I 3 ögon måste implantaten avlägsnas på grund av komplikationer orsakade av kirurgiska tekniken.

(Received May 14, 1992; accepted July 2, 1992).

Reprints may be requested from: M. Kivalo, Department of Anatomy, College of Veterinary Medicine, P.O. Box. 6, SF-00581 Helsinki, Finland. 